INTERNATIONAL FOOD

POLICY RESEARCH INSTITUTE

sustainable solutions for ending hunger and poverty

Supported by the CGIAR

IFPRI Discussion Paper 00983

May 2010

\title{
Positional Spending and Status Seeking in Rural China
}

\author{
Philip H. Brown \\ Erwin Bulte \\ Xiaobo Zhang
}

Development Strategy and Governance Division 


\section{INTERNATIONAL FOOD POLICY RESEARCH INSTITUTE}

The International Food Policy Research Institute (IFPRI) was established in 1975. IFPRI is one of 15 agricultural research centers that receive principal funding from governments, private foundations, and international and regional organizations, most of which are members of the Consultative Group on International Agricultural Research (CGIAR).

\section{PARTNERS AND CONTRIBUTORS}

IFPRI gratefully acknowledges the generous unrestricted funding from Australia, Canada, China, Denmark, Finland, France, Germany, India, Ireland, Italy, Japan, the Netherlands, Norway, the Philippines, South Africa, Sweden, Switzerland, the United Kingdom, the United States, and the World Bank.

\section{AUTHORS}

Philip H. Brown, Colby College and William Davidson Institute phbrown@colby.edu

Erwin Bulte, Wageningen University and Tilburg University erwin.bulte@wur.nl

Xiaobo Zhang, International Food Policy Research Institute

Senior Research Fellow, Development Strategy and Governance Division x.zhang@cgiar.org have not been subject to a formal external review via IFPRI's Publications Review Committee. They are circulated in order to stimulate discussion and critical comment; any opinions expressed are those of the author(s) and do not necessarily reflect the policies or opinions of IFPRI.
}

Copyright 2010 International Food Policy Research Institute. All rights reserved. Sections of this material may be reproduced for personal and not-for-profit use without the express written permission of but with acknowledgment to IFPRI. To reproduce the material contained herein for profit or commercial use requires express written permission. To obtain permission, contact the Communications Division at ifpri-copyright@cgiar.org. 


\section{Contents}

Abstract $\quad$ V

Acknowledgements vi

1. Introduction 1

2. Social Spending and the Distribution of Income 4

3. Data and Descriptive Statistics $\quad 8$

4. Empirical Results 15

5. Discussion and Conclusions 26

$\begin{array}{ll}\text { References } & 28\end{array}$ 


\section{List of Tables}

1. Summary statistics by administrative village, $2004 \quad 9$

2. Income by administrative village, 2004 and $2006 \quad 10$

3. Consumption by administrative village (2004 and 2006) and gift expenditure by administrative village (2001 and 2006)

4. Median marriage and funeral expenditures (in RMB), 1996-20061 14

5. OLS regressions for funeral expenses 17

6a. OLS regressions for wedding expenses paid by the groom's family 19

6b. OLS regressions for wedding expenses paid by the bride's family 20

7a. OLS regressions for changes in gift giving for low-income households (2004-2006) 22

7b. OLS regressions for changes in gift giving in middle-income households (2004-2006) 23

7c. OLS regressions for changes in gift giving in high-income households (2004-2006) 24

\section{List of Figures}

1. Annualized growth in per capita income, consumption, and gift spending by administrative village 13 


\begin{abstract}
Focusing on a remote area in rural China, we use a panel census of households in 26 villages to show that socially observable spending has risen sharply in recent years. We demonstrate that such spending by households is highly sensitive to social spending by other villagers. This suggests that social spending is either positional in nature (that is, motivated by status concerns) or subject to herding behavior. We also document systematic relations between social spending and changes in higher order terms of the income distribution. In particular, and consistent with theories of rank-based status seeking, we find the poor increase spending on gifts as the income distribution tightens so that local competition for status intensifies. In addition families of unmarried men (who face grim marriage prospects given China's high sex ratios, especially in poor areas) intensify their competition for status by increasing their spending on weddings. The welfare implications of spending in order to "keep up with the Joneses" are potentially large, particularly for poor households.
\end{abstract}

Keywords: positional spending, status, poverty

JEL Codes: D12, H31, I32 


\section{ACKNOWLEDGEMENTS}

We thank staff and students from Guizhou University and the International Center for Agricultural and Rural Development (ICARD) at the Chinese Academy of Social Science for their help in conducting the survey. We deeply appreciate Jing Yang, Li Xing, Shufang Zhang, and Yumei Zhang's great help in cleaning up the data. We are grateful for the comments from anonymous reviewers and participants of the Chinese Economists Society annual meetings at Nanning and the Conference on "Relativity, Inequality and Public Policy" held at Edinburgh, 5-7, June 2009. The funding support provided by the Natural Science Foundation of China (Approval numbers 70525003 and 70828002) is acknowledged. 


\section{INTRODUCTION}

Although standard economic theory assumes that individuals derive utility from absolute levels of consumption, it is well understood that people also care about how their consumption compares to that of others. One reason is that relative consumption is closely linked to social status. Concern about one's status might be based on "hardwiring" of preferences shaped by some historically distant evolutionary process, or it may simply follow because it has instrumental value today (see, for example, Postlewaite 1998). ${ }^{1}$ Regardless of its origin, however, sensitivity to relative income and consumption implies that issues such as labor supply, savings, and consumption choices are not invariant with respect to the behavior of others. The pursuit of status leaves a behavioral trail.

In the race for social status, an inherent conflict emerges between individual and social welfare, because negative externalities caused by positional spending imply inefficient equilibrium outcomes (Frank 2005, 2008). In addition to such efficiency costs, Frank (2008) noted that in U.S. counties with high income inequality, intense competition for social status leads to higher median housing prices, higher personal bankruptcy rates, and a higher incidence of divorce ${ }^{2}$

Interestingly, status may not necessarily be a luxury good because it is especially sought after by the rich. Although findings by Heffetz (2007) suggest that status seeking through conspicuous spending is only relevant for the richest half of the U.S. population, anecdotal evidence does corroborate Veblen's argument that "no class of society, not even the abjectly poor, foregoes all customary conspicuous consumption" $(1899,85)$. For instance, van Kempen (2003) demonstrated that the poor in Bolivia are willing to trade off the consumption of nonpositional goods for extra consumption of designer-label goods in an effort to "keep up with the Joneses." Similarly, Banerjee and Duflo (2007) found that the median household in Udaipur, India - where 86 percent of the population lives below the US\$2-per-day poverty line-spends 10 percent of its annual budget on festivals and 5 percent on tobacco and alcohol, which are typically consumed in social settings. This is a striking outcome for a region in which 65 percent of the men and 40 percent of the women have body mass indexes below 18.5, a figure that the World Health Organization considers to be an indicator of long-term malnutrition (WHO 1995).

Other forms of conspicuous spending by the poor include spending on funerals, marriages, and gifts. For example, Case et al. (2008) observed that South African households spend the equivalent of one year's income to bury deceased household members, while The Economist (2007) reported on "splendid" funerals in Ghana, where the typical burial costs between US\$2,000 and US $\$ 3,500$, despite 79 percent of the population living on less than US\$2 per day. In each case, such lavish spending is intended to indicate the social status of the deceased and the "quality" of the mourning family. In a similar fashion, Anderson (2007) provided evidence that high brideprices and dowries are used to attract socially desirable marital partners for one's children. The amounts involved are often substantial, with marital transfers amounting to six times the annual household income in south Asia (Rao 1993) and four times the annual household

\footnotetext{
${ }^{1}$ Relative consumption effects can also originate when status has instrumental value - perhaps because it determines access to valuable resources, such as potential mates (see, for example, Cole, Mailath, and Postlewaite 1992). Alternatively, preferences for relative consumption may be a side effect or relic from an ancient evolutionary process, such as the processing of imperfect information in a fluctuating environment. In this context, consumption by peers contains information about the state of the environment and helps us behave optimally (see, for example, Samuelson 2004).

${ }^{2}$ Moreover, considerable empirical evidence suggests that a person's well-being is affected by relative income and consumption. For example, according to Stutzer (2004), income aspirations rise with average community income in Switzerland, and yet increasing aspirations result in decreased subjective well-being. Luttmer (2005) found that self-reported happiness of people is negatively affected by higher earnings of their neighbors. Similarly, Shilpi and Fafchamps (2003) found that poor households' subjective assessment of the adequacy of their housing, food, clothing, healthcare, and schooling consumption is strongly correlated with the average consumption level of community members in Nepal. Easterlin (1995) reported a positive correlation between individual income and self-reported happiness (see also Diener et al. 1993), but found that average happiness is not highly correlated with national income and does not respond strongly to changes in income over time (see also Frank 1985a; Oswald 1997). Easterlin thus concluded that relative income is more important than absolute income as a determinant of subjective well-being - in other words, income comparisons do matter. (See Clark, Frijters, and Shields 2008 for a treatment of micro and macro evidence and an overview of theoretical approaches to explain "Easterlin's paradox.")
} 
income in Africa (Dekker and Hoogeveen 2002). Moreover, Anderson (2007) showed that marriage payments rise during periods of increasing income inequality in settings such as Bangladesh. In the context of gift exchange, Yan (1996) found that practices in China include elements intended to manipulate social relations and to challenge social status, and that competitive gift giving frequently ensues.

It is not evident, however, that escalating marital transfers or expenses related to funerals and gift giving measure more intense status seeking. For example, it could be that people respond to the behavior of their peers because of their own desire to conform. Such herding behavior may be triggered by sanctions on deviants who violate social rules or norms, positive payoff externalities, a preference for conformity, or informational cascades (Banerjee 1992; Bikhchandani, Hirshleifer, and Welch 1992). While not relevant for expenses on funerals and weddings, gift giving may serve another purpose. Rural areas in developing countries offer limited opportunities for smoothing consumption via "formal" financial and insurance markets, and self-protection and risk sharing via informal and voluntary community structures are prominent approaches to reducing exposure to risk (see, for example, Rosenzweig 1988, Coate and Ravallion 1993, Townsend 1994, Udry 1994). ${ }^{3}$ Changes in the exposure to risk could invite changing patterns of gift giving that are unrelated to status seeking. ${ }^{4}$ Thus, it is important to distinguish between the underlying mechanisms when analyzing relations between consumption of individuals and consumption of the aggregate community within which the individual resides.

For this reason, it is worthwhile to clarify two concepts - social spending and positional spending. The former is a broad category of expenditures that is at least partly motivated by the spending decisions of others and that encompasses positional spending as a special case. Positional spending, then, focuses on status seeking as the deeper motivation for a concern about relative consumption.

Distinguishing between status seeking and evolving social norms (or risk sharing) to explain observed spending patterns is far from straightforward, as it requires specific theories and detailed expenditure data for reference groups.

In this paper, we aim to make some progress toward documenting patterns of social spending in rural China and unraveling the underlying mechanisms. In order to do so, we first describe recent trends in various forms of social spending, including household expenditures on funerals, weddings, and gifts. Second, we assess the determinants of such spending, focusing on the average level of spending in the community as an important potential contributing factor. Moreover, because we have collected spending data on several goods, we can assess whether the motives behind social spending are consistent across goods. Third, consistent with the theory of rank-based status (as outlined in the next section), we explore whether changes in income distribution prompt certain groups to disproportionately change their social spending, evidence of which would suggest that status concerns may underlie these patterns. Finally, we describe some of the welfare implications of the race for status on poor households.

The analysis is undertaken via a new panel survey of households in three administrative villages in China's Guizhou province. The survey was administered to every household in the three administrative villages, which means we have a complete picture of relative status without having to rely on sampling. ${ }^{5}$ Moreover, employing panel data eliminates concerns about simultaneity and omitted variable bias, which may arise in a cross-section.

We then demonstrate that social spending in our surveyed villages has increased much faster than income. We also demonstrate correlations between funeral and gift expenditures on the one hand and

\footnotetext{
${ }^{3}$ Such sharing is usually studied by focusing on self-enforcing arrangements as subgame perfect equilibria of repeated games. Binding participation and incentive constraints typically imply limited mutual insurance possibilities, the implications of which have been studied in some detail by economists. For example, Coate and Ravallion (1993) analyzed stationary schemes; Ligon, Thomas, and Worrall (2003) considered nonstationary schemes with history-dependent transfers-blurring the distinction between insurance and credit; and Genicot and Ray (2003) analyzed coalition stability in the presence of potential defection by subgroups of individuals.

${ }^{4}$ We thank an anonymous referee for raising this important point.

${ }^{5}$ As pointed out by Santos and Barrett (2008), analyzing social networks with sample data may significantly affect the accuracy of inference.
} 
lagged levels of aggregate spending in these same areas on the other, a result that holds even when we control for income and household demographics. These patterns of social spending are consistent with the theoretical predictions of several status models but do not exclude alternative explanations, such as herding behavior. To distinguish between status seeking and other motives, we test a hypothesis based on the class of rank-based status models and link social spending to higher moments of income distribution within the reference population. We find evidence of status seeking, with the poor being especially sensitive to status concerns; within this group, status appears to be derived from spending on funerals, weddings (for the groom's family), and gifts. For middle-income and high-income households, however, increased spending on status goods appears to be better explained by evolving social norms. Finally, spending on weddings by the bride's family follows none of these patterns, suggesting that some forms of socially observable spending are subject neither to herding nor to status concerns. Hence, status seeking manifests itself differently for different types of positional goods and for different income classes.

The paper is organized as follows. In Section 2, we discuss the literature on exogenous changes in the distribution of income and status seeking. In Section 3, we describe positional spending in China, outline our empirical strategy, and describe our data. In Section 4, we present the empirical results and relate them to our model. The conclusions and discussion ensue. 


\section{SOCIAL SPENDING AND THE DISTRIBUTION OF INCOME}

We begin with a general specification that captures the idea that people care about their own behavior and payoffs relative to those of others. This paper initially focuses on status seeking as the deeper motivation for a concern about relative consumption and then returns to herding behavior and risk sharing.

We define $x_{i}$ as an individual's own consumption of a "visible" good that may confer status when consumed by individual $i$; we define $y$ as that individual's consumption of a good that is not visible (and hence cannot confer status). We define $\ddot{\mathfrak{D}}$ as a measure of spending on good $x$ by others in the reference population (see below), $Z_{\mathrm{i}}$ as a vector of socioeconomic and demographic variables, and $p$ as the relative price of good $x$. We assume agent $i$ 's utility as

$$
U_{i}=U\left(x_{i}, \hat{x} ; Z_{i} ; p, I\right),
$$

in which we have used the budget constraint $I_{i}=p x_{i}+y_{i}$ to eliminate $y$ so that $I$ denotes income. If the individual's utility is influenced by relative spending - for example, by differences between $x_{i}$ and $\ddot{\mathfrak{D}}$ then one possible specification of (1) is

$$
U_{i}=\alpha S\left(x_{i}-\hat{x}\right)+(1-\alpha) V\left(x, I-p x_{i}\right)
$$

where $S$ is a subutility function that captures the benefits of status, $V$ is a subutility function that captures utility from an individual's own consumption, and $0 \leq \alpha \leq 1$ is a parameter that measures the strength of concerns about status. For $\alpha \rightarrow 0$, the problem reduces to a conventional utility-maximization exercise in which social spending plays no role. For $\alpha>0$, the specification in (2) implies that people derive utility (or disutility) from spending more (or less) than others on visible goods.

It is easy to show that introducing a concern about the relative consumption of visible goods implies that spending on the social good is increased, relative to spending in conventional models (where $\alpha=0$ ). However, the comparative statics indicating whether people spend more or less on social goods in response to changes in the expenditures of their peers are less clear. Solving for $\partial U_{i} / \partial x_{i}=0$ and then differentiating yields

$$
\frac{\partial x_{i}}{\partial \ddot{\mathfrak{x}}}=\frac{\alpha S_{x x}}{\alpha S_{x x}+(1-\alpha) V_{x x}-2 p(1-\alpha) V_{x y}+(1-\alpha) p^{2} V_{y y}},
$$

where variable subscripts denote (partial) derivatives. The denominator of the right hand side of (3) is negative, by the requirement that the maximization problem is concave; the sign of the numerator, however, may be negative or positive, depending on whether $S(\cdot)$ is concave or convex. Thus, the sign of $\partial x_{i} / \partial \ddot{\mathfrak{p}}$ is ambiguous, and both "follower" $\left(\partial x_{i} / \partial \ddot{\mathfrak{p}}>0\right)$ and "deviant" behavior $\left(\partial x_{i} / \partial \ddot{\mathfrak{p}}<0\right)$ may ensue. Concave utility from status $S_{x x}<0$ implies that an increase in positional spending by others triggers a "keeping up with the Joneses" response in agent $i$. Concave utility implies that the marginal value of status falls as one has more of it, and status seeking generates social spending decisions as strategic complements. In contrast, convex utility from status implies that the marginal utility of status increases as one acquires more of it, akin to risk-loving preferences in conventional models. Such preferences imply behavior opposite the tendencies observed in the reference group, and this outcome could describe the behavior of fashion leaders and individuals in counterculture groups. Hence, a fundamental result is that a concern for social status yields ambiguous predictions for the behavior of individuals in response to changes in the status-seeking behavior of others. ${ }^{6}$ However, the most likely case (and the one

\footnotetext{
${ }^{6}$ The ambiguity of $\partial x_{i} / \partial \ddot{\mathfrak{B}}$ is not conditional on the assumption that status utility is specified as $S=S\left(x_{i}-\ddot{\mathfrak{D}}\right)$. For example, qualitatively similar results are obtained when $S=S\left(x_{i} / \ddot{\mathscr{\theta}}\right)$ instead (see, for example, Clark and Oswald 1998).
} 
corroborating the conventional perspective on status seeking) is that the concave utility potentially results in spending races.

Herein lies a problem. The standard status-seeking specification predicts $\partial x_{i} / \partial \ddot{\mathfrak{p}}>0$, but this is exactly what a simple herding model based on an (exogenously) evolving norm would predict. For example, relabel $\ddot{\mathfrak{B}}_{j}(t)$ as a spending norm on visible goods in community $j$ at time $t$. If we redefine utility as

$$
U_{i}=\beta S\left|x_{i}-\hat{x}\right|+V\left(x, I-p x_{i}\right)
$$

where $\beta$ is a coefficient measuring the disutility associated with deviations from the spending norm, then we would also obtain $\partial x_{i} / \partial \ddot{\mathfrak{p}}>0$ as a rational equilibrium response.

To distinguish between status seeking and herding induced by an evolving norm, we add structure to the model. Following Frank (1985b), Robson (1992), Hopkins and Kornienko (2004; hereafter HK), and Haagsma and van Mouche (2007), one might augment utility functions with a term that captures the ordinal "rank" of the agent in a reference population. ${ }^{7}$ This term may be captured by

$$
U_{i}=U\left(x_{i}, F\left(x_{i}\right), Z_{i} ; p, I\right),
$$

where $F(\cdot)$ denotes a cumulative density function. The social rank of agents varies positively with the number of other agents that it dominates in terms of status spending; hence, $U(\cdot)$ must be increasing in $F(\cdot)$. The advantage of this specification is that status is not only determined by an individual's own spending behavior relative to average behavior in the population, but that higher order terms of the spending distribution also matter. Thus, the distribution of income determines the intensity of the local contest for higher rank.

To illustrate, suppose that some households within the reference population receive an exogenous increase in income. ${ }^{8}$ The impact of a change in income distribution on positional spending is analyzed by HK, where status is modeled as the agent's rank in terms of consumption of the positional good. ${ }^{9}$ Specifically, building on Frank (1985b) and Robson (1992), status is defined as

$$
S(x, F(x))=a F(x)+(1-a) F^{-}(\mathrm{x})+s,
$$

where $F(x)$ measures the mass of individuals with lower or equal consumption of the status-conferring good; $F^{-}(x)$ is the mass of individuals with strictly lower consumption of the status-conferring good (to avoid nonuniqueness of the equilibria), and $s$ is a parameter that captures the "basic," or minimum, level of status that accrues to all community members, including the one with lowest social rank, and that thus measures the intensity of competition for status. HK consider the following specification of utility:

$$
U(\cdot)=V(x, y) S(x, F(x)) \text {. }
$$

\footnotetext{
${ }^{7}$ Alternatively, in the tradition of Duesenberry (1949), Pollak (1976), Oxoby (2004), and others, utility functions may be augmented with a term that captures average consumption within the reference population $(\bar{x})$, such that the utility function is specified as $U_{i}=U\left(x_{i},\left(x_{i} / \bar{x}\right), Z_{i} ; p, I\right)$. Depending on what we are willing to assume with respect to the specification of $U$, positional spending might again emerge as strategic complements or substitutes, but the most likely specification again produces $\partial x_{i} / \partial \bar{x}>0$. Unfortunately, not much else can be teased out of this model that allows us to distinguish between status seeking and norm-induced herding.

${ }^{8}$ The income distribution may change due to many factors. However, in the context of Chinese villages, one key factor is the inflow of money via remittances for some villagers and not for others.

${ }^{9} \mathrm{HK}$ model the case of a continuum of individuals. Especially in the context of rural communities, however, a model based on a discrete number of agents, such as that of Haagsma and van Mouche (2007), may be more appropriate. Although the continuity assumption is not innocent in general, both the continuous and discrete models yield the ambiguous comparative statics with respect to exogenous changes in income distribution.
} 
They also introduce a budget constraint so that the model may be solved. In the presence of a positive exogenous shock to the income of some households in the reference population (due to remittances from family members in urban areas, for example), the Nash equilibrium response of (most) other households is to increase spending on status-conferring goods; this response is also an effort of those families to preserve their rank and status. ${ }^{10}$ A new equilibrium status ranking (corresponding with the ex post distribution of income) ensues. Households not receiving the income shock may find themselves surpassed on the social ladder; if so, they may experience a fall in status and utility. Of course, such households also suffer, because increased positional spending lowers utility from their own consumption by reducing $V^{*}$.

Depending on assumptions with respect to $s$ (that is, the residual status for the lowest-ranked individual in society), social spending of the poorest within society may intensify or relax in response to changes in the income distribution. Whenever $s>0$ - that is, whenever the lowest-ranked individual has some status - $\mathrm{HK}$ found that a subset of the poorest not receiving remittances may decrease positional spending in equilibrium, because changing the income distribution implies changing the intensity of (local) competition for status at the bottom. Suppose, for example, that a changed income distribution implies "upgrading" some poor people to the middle-income echelon of the reference population such that the income distribution's density mass shifts away from the low-income tail and toward the center. As a result, competition for status becomes less intense at the bottom, and the incentive to engage in strategic status seeking is mitigated, enabling the poorest to relax their spending on positional goods and to move toward the "conventional" (that is, the non-status seeking) efficient allocation of income. That is, they may buy more $y$ and less $x$. ${ }^{11}$

In contrast, when $s=0$, implying pariah-like status for the lowest-ranked individual, the comparative statics are unambiguous. The case of $s=0$ might be a realistic scenario when, for example, competition for mates depends on status and when the lowest-ranked individual cannot attract a spouse. In such a context, raising average income triggers a scramble for status that extends all the way down to the bottom echelons of the income distribution - that is, $\partial x_{i} / \partial \ddot{\mathfrak{p}}>0$ for all community members. Even the poorest of the poor then raise their conspicuous consumption in response to an increase in income of some of their fellow villagers (see HK for details).

The rank-based status model allows us to distinguish between status seeking and norm-induced herding as causal mechanisms of social spending, because it relates social spending to a measure of income inequality. Assume there are two communities that are identical in all respects but one. Specifically, when comparing the density functions of the income distributions, Community 1 has more probability mass in the tails of the distribution than does Community 2 . The HK model predicts that status seeking will be more intense for the poor and the rich in Community 1 and for households with an income closer to the mean in Community 2. More intense competition for status translates into greater social spending (an exception exists for the poorest whenever $s=0$, because, in a desperate effort to keep up, they may increase positional spending in response to a decrease in local density). Although changing the distribution of income has ambiguous effects on overall status seeking within the community, the model produces predictions for social spending conditional on an individual's own income and the overall distribution of income within the community. In contrast, there is no reason to suspect that norm-induced herding is guided by income distribution. We exploit these insights to identify status seeking in our data and to distinguish status seeking from herding behavior.

Similarly, we can distinguish between positional spending and risk sharing. First, and obviously, though risk sharing may materialize via gift giving, it is unlikely to matter for expenses on funerals and

\footnotetext{
${ }^{10}$ Hence, outcomes may emerge where "everyone increases conspicuous consumption in order to improve status, but any gain in status is cancelled out by the similarly increased expenditures of others. Such an economy can be described as a Lewis Carroll 'Red Queen' economy, in which 'it takes all the running you can do to keep in the same place'" (Hopkins and Kornienko 2004, p. 1086).

${ }^{11}$ However, the net effect on welfare considering both the re-allocation of consumption and the fall in status is necessarily negative, even for the poorest households; see HK.
} 
weddings. These latter categories thus provide useful expenditure categories in which to search for evidence of status seeking. Second, it is not obvious that spending for risk sharing purposes is responsive to higher order terms of income distribution. In particular, empirical work by Fafchamps and Gubert (2007) on risk sharing in the Philippines documents that wealth differences do play a role in the formation of risk-sharing links, in that poor villagers try to team up with richer ones. Gift giving occurs across the income distribution spectrum, and personalized links with individuals across all income groups matter (as opposed to the local density of the income density distribution). ${ }^{12}$ To further attenuate concerns that gift giving captures risk sharing rather than status seeking, we control for negative shocks to health status and income in the models seeking to explain gift giving.

\footnotetext{
12 There are two additional reasons that gift-giving data are unlikely to conflate status seeking and risk sharing. First, Fafchamps and Lund (2003) highlighted the important role of flexible zero-interest loans (rather than gifts) within networks of friends and relatives. Our dataset distinguishes between zero-interest loans and gifts, making it unlikely that these are confused by the respondents. Second, the respondents indicated that gift giving is associated with specific occasions. Traditionally, these occasions have included weddings and funerals. More recently, they also include abortion and sterilization.
} 


\section{DATA AND DESCRIPTIVE STATISTICS}

The economic and structural transformations occurring in China in recent decades have generated one of the most dramatic migration dynamics in human history, unleashing entrepreneurship and suggesting that remittances from migration and income from nonfarm activities may challenge the existing social order in villages. Moreover, new occasions for gift giving (Yan 1996), as well as large increases in conspicuous consumptive investment relative to productive investment (de Brauw and Rozelle 2008), could be indicative of both status seeking and norm-induced herding. Thus, rural China is a good candidate for studying the rank-based status model outlined above.

The data for this study come from a detailed panel survey of households in Guizhou Province, China. ${ }^{13}$ With a poverty rate double the national average, Guizhou is the poorest province in China, an ideal setting for studying the implications of social spending on poor households. The survey site is Puding County, which consists of 11 townships, 317 administrative villages, ${ }^{14}$ and a total population of 402,000. Per capita income in Puding County is above the provincial median but below the provincial mean, suggesting that its income profile is representative of Guizhou as a whole. At the end of 2002, approximately 120,000 people in Puding (31 percent of the population) were officially designated as poor (PAO 2003). About 94 percent of the population resides in rural areas, and agricultural labor accounts for approximately two-thirds of the total labor force. More than 20 ethnic groups are represented in Puding, including Han (the ethnic majority on China), Miao, Buyi, Gelao, and Yi; in total, ethnic minorities make up about 20 percent of the population.

Three administrative villages that represent the broad range of economic development in Puding were chosen by survey enumerators, including one of the authors. In late 2004, a census-type survey of all 805 households in the 26 natural villages making up the three administrative villages was administered. ${ }^{15}$ A follow-up survey administered in early 2007 (reflecting the year 2006) included 833 households, including several that resulted from new marriages. The surveys collected detailed information on demographics, income, consumption, and transfers. Information was collected for each household member, including members who were working outside the county at the time of the surveys.

Table 1 presents summary statistics for each of the three administrative villages in 2004. The first administrative village comprised 11 natural villages, totaling 257 households, and is located 10 kilometers from the county seat over rough roads, limiting marketing opportunities for people in this village. In addition, water shortages are severe during dry times of the year in this village. The second administrative village comprises 151 households in five natural villages and is located 8 kilometers from the county seat. Although the distance from markets is similar to the first administrative village, a new road from this second village to the county seat has greatly improved access, bolstering fruit and vegetable production in recent years. The third administrative village comprises 10 natural villages with 393 households in total. It is a short walk to the county seat, so access to markets is trivial for residents of the third village. All of the villages are land-poor, averaging just $1 \mathrm{mu}$ of cultivated land per person. ${ }^{16}$ However, whereas 80 percent of the land in the third administrative village is flat (and therefore ideally suited to rice production), only 40 percent and 20 percent of the land in the first and second administrative villages, respectively, is flat. Thus, not only do residents in the third administrative village enjoy more nonfarm employment opportunities than people in either of the other villages, but they also have the best farming conditions.

\footnotetext{
${ }^{13}$ Data collection efforts were supported by the International Food Policy Research Institute, the Chinese Academy of Agricultural Science, and Guizhou University.

${ }^{14}$ An administrative village is a bureaucratic entity comprised of several "natural" or "typical" villages.

${ }^{15}$ Officially, the three administrative villages have 987 households, but no one was home during any of three separate visits to 183 households. According to neighbors, most of these households had migrated out of the county and were unlikely to return. After data cleaning, 801 households remained in the analysis. In the 2007 survey, 833 households were surveyed. During the intervening time, some young people had formed new households and some households were relocated into the area from more remote places as part of a poverty-alleviation program, explaining the 28-household gain.

${ }^{16}$ One $m u$ is equal to $666^{2} / 3$ square meters, which is slightly smaller than one-sixth of an acre.
} 
Table 1. Summary statistics by administrative village, 2004

\begin{tabular}{|c|c|c|c|c|}
\hline & $\begin{array}{r}\text { Admin. } \\
\text { Village 1 }\end{array}$ & $\begin{array}{r}\text { Admin. } \\
\text { Village } 2\end{array}$ & $\begin{array}{r}\text { Admin. } \\
\text { Village } 3\end{array}$ & Total \\
\hline Number of natural villages & 11 & 5 & 10 & 26 \\
\hline Total number of households & 257 & 151 & 393 & 801 \\
\hline Total population & 1,089 & 535 & 1,449 & 3,073 \\
\hline Distance to the county seat $(\mathrm{km})$ & 10.0 & 8.0 & 2.5 & 6.8 \\
\hline Per capita cultivated land $(\mathrm{mu})$ & 0.87 & 0.86 & 1.10 & 0.98 \\
\hline Share of total land classified as being flat (\%) & 40.0 & 20.7 & 80.0 & 53.4 \\
\hline Share of households headed by males (\%) & 93.5 & 94.8 & 91.6 & 92.8 \\
\hline Average education of the household head (years) & 2.87 & 3.06 & 3.98 & 3.44 \\
\hline Share of households headed by ethnic minorities (\%) & 76.6 & 12.6 & 6.7 & 30.8 \\
\hline $\begin{array}{l}\text { Average share of household members aged 11-29, } \\
\text { unmarried }(\%)\end{array}$ & 15.9 & 15.7 & 14.7 & 16.6 \\
\hline $\begin{array}{l}\text { Average share of household members aged } 60 \text { and } \\
\text { above }(\%)\end{array}$ & 14.2 & 17.9 & 12.5 & 14.1 \\
\hline
\end{tabular}

Source: Authors' survey data.

Although the demographic profile of the three administrative villages is similar in terms of the share of households headed by men ( 93 percent), there are some striking differences. Foremost, ethnic minorities make up 76 percent of the household members in the first administrative village. By contrast, minorities in the second and third villages make up only 13 percent and less than 7 percent of their populations, respectively. Second, whereas the education level of household heads averages just 3.4 years, household heads in the third administrative village have an average of a full year more education than household heads in the first administrative village. Third, households in the second administrative village include more elderly people than households in either of the other two administrative villages.

Table 2 describes the various components of household income. Per capita income in 2004 ranged from 1,009 $\mathrm{RMB}^{17}$ in the first administrative village to 1,749 RMB in the third village. Between 2004 and 2006, per capita net income rose by 5 percent in the first administrative village; however, this figure was dwarfed by the 13 percent income growth in the second administrative village and the 18 percent income growth seen in the third administrative village. Indeed, by 2006, per capita income in the third administrative village was well more than double that in the first administrative village. The average per capita income for all three administrative villages was 1,404 RMB in 2004 and 1,817 RMB in 2006. The Gini index ranges from 41.6 in the third administrative village in 2004 to 52.9 in the second village in 2006. Each of the three villages demonstrated a high degree of both skewness and kurtosis in income distribution. ${ }^{18}$

\footnotetext{
${ }^{17}$ In 2006, RMB $1=$ US $\$ 0.12$ at official exchange rates.

${ }^{18}$ The skewness statistic measures the relative asymmetry of per capita income in the natural village; a positive (negative) skewness statistic implies a longer right (left) tail. It is the third standardized moment, calculated as $\frac{1}{n} \sum_{i=1}^{n}\left(y_{i}-\bar{y}\right)^{3} /\left(\frac{1}{n} \sum_{i=1}^{n}\left(y_{i}-\bar{y}\right)^{2}\right)^{3 / 2}$, where $y_{i}$ is household $i$ 's per capita income and $\bar{y}$ is the mean per capita income in the village. The kurtosis statistic measures the peakedness of the distribution of per capita income in the natural village. It is the fourth standardized moment, calculated as $\frac{1}{n} \sum_{i=1}^{n}\left(y_{i}-\bar{y}\right)^{4} /\left(\frac{1}{n} \sum_{i=1}^{n}\left(y_{i}-\bar{y}\right)^{2}\right)^{2}-3$.
} 
Table 2. Income by administrative village, 2004 and 2006

\begin{tabular}{|c|c|c|c|c|c|c|c|c|}
\hline & \multicolumn{2}{|c|}{ Admin. Village 1} & \multicolumn{2}{|c|}{ Admin. Village 2} & \multicolumn{2}{|c|}{ Admin. Village 3} & \multicolumn{2}{|c|}{ Total } \\
\hline & 2004 & 2006 & 2004 & 2006 & 2004 & 2006 & 2004 & 2006 \\
\hline Per capita annual income (RMB) & 1,009 & 1,111 & 1,274 & 1,638 & 1,749 & 2,420 & 1,404 & 1,817 \\
\hline Income inequality (Gini) & 43.7 & 46.3 & 41.9 & 52.9 & 41.6 & 42.7 & 44.2 & 49.0 \\
\hline Skewness of per capita annual income & 4.2 & 2.9 & 1.8 & 4.6 & 2.9 & 1.9 & 3.2 & 3.1 \\
\hline Kurtosis of per capita annual income & 34.1 & 14.5 & 6.5 & 28.5 & 15.9 & 8.2 & 19.6 & 17.8 \\
\hline \multicolumn{9}{|l|}{ Main sources of income $(\%)$} \\
\hline Farming & 26.3 & 26.7 & 31.0 & 37.4 & 37.0 & 31.5 & 33.3 & 31.4 \\
\hline Livestock & 12.3 & 13.3 & 9.1 & 10.9 & 6.0 & 3.4 & 8.1 & 6.8 \\
\hline Local nonfarm and self-employment & 31.2 & 18.4 & 22.1 & 18.4 & 39.9 & 40.6 & 34.9 & 32.2 \\
\hline Remittance from migrants outside the county & 7.8 & 22.4 & 10.9 & 10.2 & 7.3 & 10.7 & 8.0 & 13.1 \\
\hline Disaster relief, antipoverty programs, and deforestation subsidies & 5.1 & 2.9 & 2.5 & 6.9 & 1.9 & 0.5 & 2.8 & 2.0 \\
\hline Gift income & 3.1 & 3.9 & 12.1 & 7.0 & 5.2 & 8.7 & 5.8 & 7.4 \\
\hline Other income & 14.2 & 12.4 & 12.2 & 9.1 & 2.7 & 4.7 & 7.1 & 7.1 \\
\hline
\end{tabular}

Source: Authors' survey data. 
Access to markets and to off-farm employment appear to be very important in combating poverty; 34 percent and 28 percent of the households in the first and second administrative villages, respectively, earned less than the national poverty line of $680 \mathrm{RMB}$, while only 13 percent of the households in the third village did. In 2004, agricultural income accounted for 43 percent of total income, while off-farm work accounted for 35 percent. The share of income derived from agriculture increased 8 percentage points between 2004 and 2006 in the second village and decreased 8 percentage points over the same period in the third village. Remittances from migrants outside the county accounted for 8 percent of total income in 2004. Remittances were especially important in the first administrative village, which saw the share of income derived from remittances increase from 8 percent to 22 percent over the two-year period. By 2006, remittances made up 13 percent of household income, on average.

Other important sources of income include a series of antipoverty subsidies from the central and provincial governments (accounting for 3 percent of total income in 2004 and 2 percent in 2006) and gifts (accounting for 6 percent of income in 2004 and more than 7 percent of income in 2006). The rise in income derived from gifts was especially dramatic in the third administrative village.

Per capita consumption in the first administrative village was a very low 937 RMB in 2004, which was slightly more than half the level in the third village (Table 3). Despite such heterogeneity in per capita consumption levels, consumption grew steadily across all three administrative villages between 2004 and 2006, averaging 13 percent at an annualized rate. Nearly half of households' total consumption was allocated to food in 2004. The second-largest expenditure was medical care, accounting for about 16 percent of total living expenditures. Fuel, education, and gift spending each represented about 8 percent of total expenditure in 2004. By 2006, the share of expenditures allocated to food dropped to 42 percent, while medical care accounted for 16 percent of expenditures. The share of spending on gifts and festivals soared, increasing nearly 76 percent, from 8 percent to 14 percent. Figure 1 shows the dramatic extent to which growth in gift expenditures outstripped growth in per capita income over the survey period. 
Table 3. Consumption by administrative village (2004 and 2006) and gift expenditure by administrative village (2001 and 2006$)$

\begin{tabular}{|c|c|c|c|c|c|c|c|c|}
\hline & \multicolumn{2}{|c|}{ Admin. Village 1} & \multicolumn{2}{|c|}{ Admin. Village 2} & \multicolumn{2}{|c|}{ Admin. Village 3} & \multicolumn{2}{|c|}{ Total } \\
\hline & 2004 & 2006 & 2004 & 2006 & 2004 & 2006 & 2004 & 2006 \\
\hline $\begin{array}{l}\text { Per capita consumption }(\mathrm{RMB})^{1} \\
\text { Main expenditures }(\%)\end{array}$ & 937 & 1,192 & 1,201 & 1,528 & 1,683 & 2,204 & 1,334 & 1,725 \\
\hline Food & 53.8 & 51.1 & 47.1 & 42.9 & 45.4 & 38.5 & 47.8 & 42.2 \\
\hline Clothing & 4.4 & 4.4 & 3.1 & 3.7 & 4.0 & 4.9 & 4.0 & 4.6 \\
\hline Fuel & 5.9 & 6.4 & 5.4 & 6.9 & 10.2 & 9.5 & 8.4 & 8.3 \\
\hline Telephone & 1.1 & 2.1 & 1.3 & 2.4 & 1.5 & 3.5 & 1.4 & 3.0 \\
\hline Medical care & 14.1 & 16.7 & 24.7 & 16.8 & 15.2 & 15.2 & 16.4 & 15.8 \\
\hline Education & 9.0 & 10.0 & 7.9 & 12.2 & 8.8 & 12.3 & 8.7 & 11.7 \\
\hline \multirow[t]{2}{*}{ Gift and festival spending } & 6.4 & 9.2 & 6.8 & 13.9 & 8.9 & 15.9 & 7.9 & 13.9 \\
\hline & 2001 & 2006 & 2001 & 2006 & 2001 & 2006 & 2001 & 2006 \\
\hline Median per capita gift expenditure $(\mathrm{RMB})^{2}$ & 16 & 62.5 & 20 & 150 & 80 & 250 & 33.3 & 150 \\
\hline Median gift to direct relatives per occasion $(\mathrm{RMB})^{3}$ & 30 & 50 & 30 & 50 & 50 & 100 & 40 & 60 \\
\hline Median gift to nonrelatives per occasion $(\mathrm{RMB})^{3}$ & 10 & 20 & 15 & 30 & 25 & 50 & 20 & 30 \\
\hline
\end{tabular}

Source: Authors' survey data.

Notes: ${ }^{1}$ Excludes expenditures on housing, durable goods, and weddings/funerals of family members.

${ }^{2}$ Measured as the median of the total household expenditure on gifts divided by the number of members in the giving household.

${ }^{3}$ Measured as the median of the "typical" gift made in the previous year by each household per occasion. 
Figure 1. Annualized growth in per capita income, consumption, and gift spending by administrative village

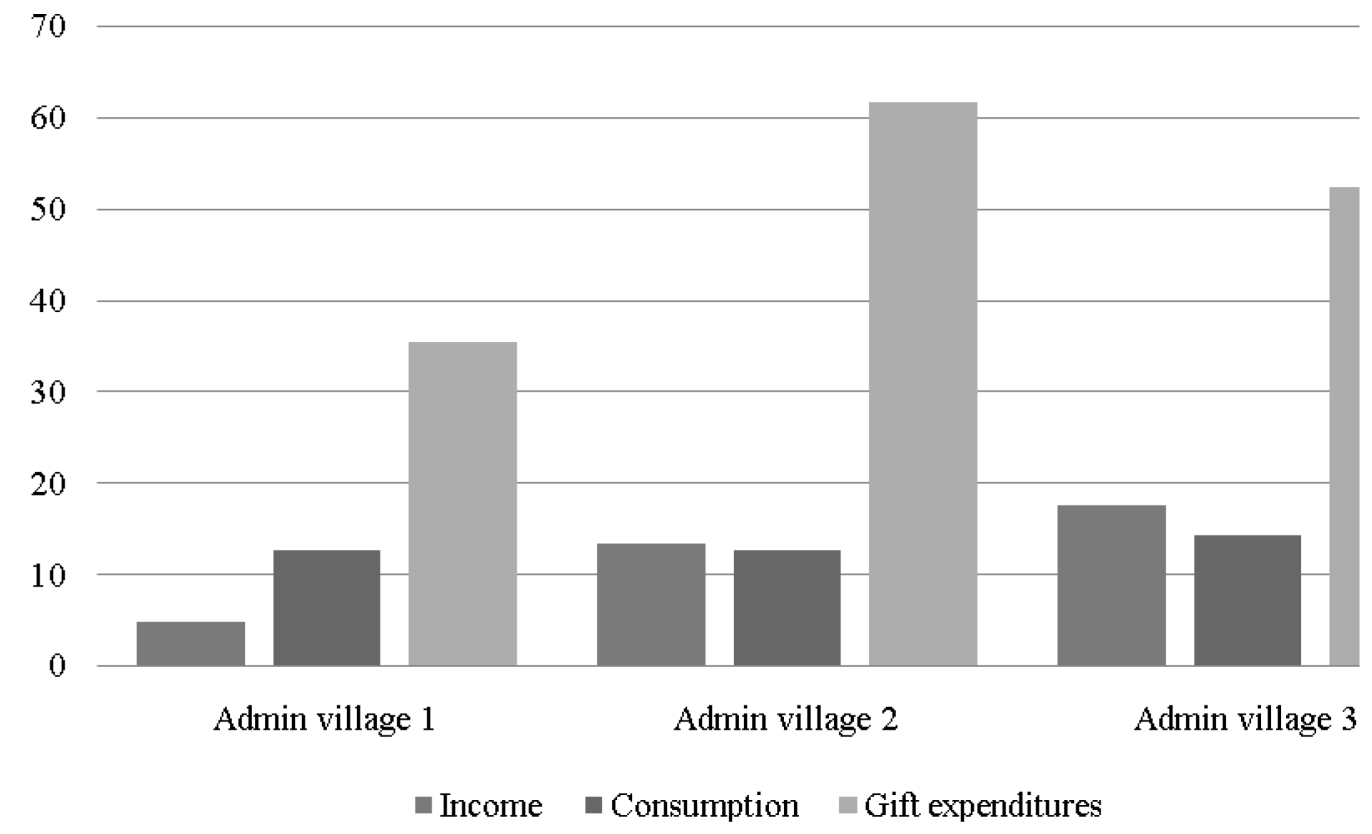

Source: Author's creation based on data collection.

As shown in the lower panel of Table 3, the median level of per capita spending on gifts (measured as total household expenditures on gifts divided by the number of members in the giving household) also increased dramatically, rising from $16 \mathrm{RMB}$ to $63 \mathrm{RMB}$ in the first administrative village, from $20 \mathrm{RMB}$ to $150 \mathrm{RMB}$ in the second village, and from $80 \mathrm{RMB}$ to $250 \mathrm{RMB}$ in the third village. The 2007 survey asked about the typical value of gifts given to direct relatives and the typical value of gifts given to nonrelatives during weddings and other major events in 2001 and 2006. The median value of gifts given at each occasion climbed from 40 RMB to 60 RMB for direct relatives, while the value of gifts given to nonrelatives increased from $20 \mathrm{RMB}$ to $30 \mathrm{RMB}$. Thus, the value of gifts increased substantially over the study period.

As in many parts of the world, weddings in China are occasions that call for significant expenditures. Typically, the groom and/or his family are responsible for paying the brideprice, a marketclearing mechanism that compensates a bride's family for rearing her and investing in her human capital (Zhang and Chan 1999). The brideprice is often accompanied by gifts to the bride herself (which may include major durables and even housing). Furthermore, the groom is responsible for paying for most of the wedding ceremony (Yan 1996). Because most marriages in rural China are arranged, many of these expenses are negotiated and incurred before the actual wedding ceremony. Dowry, by contrast, is an intergenerational transfer from the bride's parents to the bride, typically funded out of the brideprice. ${ }^{19}$ The bride's family may share the cost of the wedding ceremony, often when large numbers of unexpected guests attend the ceremony (Yan 1996).

Table 4 lists each of the above expenditures for weddings taking for 1996 through 2006 (not to be confused with gifts to the wedding couple by guests, as these are included in the gift-giving variable). Because there are relatively few weddings in any given year in a village, the table reports the mean for

\footnotetext{
${ }^{19}$ Scholars have explained the relatively large dowries in rural China as vehicles for prestige building (Liu 2000), insurance against mistreatment of daughters by their in-laws (Brown 2009), and efficient premortem inherences in contexts in which women leave their natal families at marriage (Botticini and Siow 2003).
} 
each category across all three administrative villages. Wedding expenditures for the groom and his family increased over the period, with a mean nominal year-on-year increase of 10.1 percent. In 2006, for example, the mean wedding cost the groom's family $11,805 \mathrm{RMB}$, which is approximately 5.5 times per capita income in these three administrative villages. ${ }^{20}$ During this period, the expenditure for the bride's side increased by 9.0 percent per year. The groom and his family clearly bore most of the financial burden for weddings in the surveyed area.

Funerals present another opportunity for conspicuous social spending on the part of the decedent's family. Funerals typically last three days and attract friends, relatives, and well-wishers. The funeral is generally followed by a simple meal, with most of the village in attendance (Whyte 1988), though more recent anthropological evidence suggests that these meals have evolved into elaborate (if unhappy) banquets. Indeed, between 2004 and 2006, the average funeral expenditure exceeded 5,800 RMB, which is approximately 58 percent higher (in nominal terms) than the average funeral expense between 1996 and 2003. For both weddings and funerals, all of the surveyed households kept detailed records of expenditures, as well as of gifts received, ${ }^{21}$ implying that recall error on such spending is likely to be minimal, even over long periods.

Table 4. Median marriage and funeral expenditures (in RMB), 1996-20061

\begin{tabular}{|c|c|c|c|c|c|c|c|c|}
\hline \multirow[b]{2}{*}{ Year } & \multicolumn{4}{|c|}{ Wedding: Groom's Expenditures } & \multicolumn{3}{|c|}{ Wedding: Bride's Expenditures } & \multirow{2}{*}{$\begin{array}{r}\text { Funerals } \\
\text { Total } \\
\text { Expenditure }\end{array}$} \\
\hline & $\begin{array}{c}\text { Bride } \\
\text { price }\end{array}$ & $\begin{array}{r}\text { Gift to } \\
\text { Bride }\end{array}$ & Ceremony & $\begin{array}{r}\text { Total } \\
\text { Expenditure }\end{array}$ & Dowry & Ceremony & $\begin{array}{r}\text { Total } \\
\text { Expenditure }\end{array}$ & \\
\hline 1996 & 2,036 & 679 & 1,786 & 4,500 & 1,300 & 1,857 & 3,157 & 2,688 \\
\hline 1997 & 1,572 & 868 & 950 & 3,852 & 2,308 & 792 & 3,100 & 3,471 \\
\hline 1998 & 2,188 & 773 & 1,303 & 5,211 & 1,858 & 1,167 & 3,025 & 3,170 \\
\hline 1999 & 1,165 & 702 & 1,125 & 3,634 & 2,186 & 1,643 & 3,829 & 4,328 \\
\hline 2000 & 3,200 & 646 & 1,957 & 6,250 & 2,279 & 651 & 2,929 & 4,393 \\
\hline 2001 & 2,657 & 2,552 & 2,162 & 7,371 & 3,767 & 1,877 & 5,644 & 3,388 \\
\hline 2002 & 2,539 & 1,426 & 1,912 & 7,347 & 2,818 & 1,718 & 4,536 & 3,402 \\
\hline 2003 & 2,996 & 2,171 & 2,396 & 7,891 & 3,657 & 1,486 & 5,143 & 4,655 \\
\hline 2004 & 5,888 & 803 & 2,931 & 10,423 & 2,743 & 1,500 & 4,243 & 6,150 \\
\hline 2005 & 3,825 & 1,814 & 2,123 & 9,486 & 6,296 & 1,336 & 7,633 & 5,156 \\
\hline 2006 & 5,186 & 2,006 & 3,875 & 11,805 & 3,745 & 3,757 & 7,502 & 6,175 \\
\hline
\end{tabular}

Source: Authors' survey data.

Notes: Recalled during the 2007 survey.

\footnotetext{
${ }^{20}$ In addition, the groom is responsible for building a house for the newly married couple in the sampled areas, an expense that far exceeds even the cost of the wedding.

${ }^{21}$ Yan (1996) wrote, "Ritualized gift giving is also associated with the custom of making and preserving gift lists. Gift lists are homemade books on red paper (funeral gift lists are made on yellow paper) inscribed with a traditional Chinese calligraphy brush. They serve as a formal record of all gifts received by the host of a family ceremony."
} 


\section{EMPIRICAL RESULTS}

In this section, we seek to identify the determinants of social spending. Specifically, we seek to relate spending patterns to the rank-based status model outlined in Section 2. Because expenditures related to funerals and weddings cannot be conflated with risk sharing, we start with these categories, turning to gift giving later.

Table 5 presents the ordinary least squares (OLS) regression for the determinants of expenditures on funerals. The median level of spending for each funeral in the natural village in the previous year captures social spending in the reference group. ${ }^{22}$ To help distinguish between status seeking and herd behavior (both of which are consistent with positive estimates for median spending in the previous year), we include in the model measures of the income distribution; dummies for low (lowest quartile), middle (second and third quartiles), and high (top quartile) income groups; and income distribution $\times$ income group interactions. Each column represents the results for a different measure of the income distribution. Specifically, we control for variation in the income distribution across natural villages via the Gini index for per capita household income in the natural village, the skewness statistic for per capita household income in the natural village (SK), the kurtosis statistic for per capita household income in the natural village $(\mathrm{KT})$, and an interaction between skewness and kurtosis $(\mathrm{SK} \times \mathrm{KT})$ as additional regressors. While the Gini index provides a snapshot of overall inequality, the latter three measures capture the distribution density of households with similar incomes. Statistically significant interaction terms provide evidence in favor of the notion that spending on weddings reflects positional concerns and is not merely herding behavior.

Given the high degree of heterogeneity across villages (described in Section 3), we also include a series of demographic variables that capture the household head's sex, education, and ethnicity and the age distribution of household members (measured by the share of unmarried household members aged 11-29 and the share who are over age 60) for 2006. Because village cadres are normally engaged in more social events than others, we include a dummy variable for households with a cadre. To control for unobserved heterogeneity, our estimates also include fixed effects at the level of the administrative village.

Among the 170 households that experienced a death in the previous 10 years, the median expenditure on funerals in the previous year positively affects funeral expenditures at the 5 percent significance level; ceteris paribus, a 1 percent increase in the median expenditure on funerals in the previous year raises predicted funeral spending by approximately 0.18 percent. These results suggest that funeral expenses reflect social spending. Controlling for income and other correlates, households that were headed by males in 2006 spent 63 percent less on funerals than households that were headed by women, suggesting that wives throw more lavish funerals for their deceased husbands than vice versa. Ceteris paribus, households with a disproportionate share of older household members also spend more on funerals, as do households with a larger share of young unmarried members. Consistent with the results shown below, one possible explanation is that such households may signal the quality of their unmarried members through such visible forms of spending.

The income distribution $\times$ income group interactions indicate that poor households spend more on funerals when there is a greater density of households with similar income in the natural village. The interaction term is statistically significant at the 10 percent level for all distribution proxies but the Gini coefficient, which measures inequality over the whole distribution of incomes, thereby failing to distinguish between the intensity of competition in the left and right tails. The other interaction results for the poor shown in Table 5 are incompatible with herding behavior, suggesting that funeral spending is indeed positional and that the poor feel the greatest pressure to compete. These results are consistent with

\footnotetext{
${ }^{22}$ We also estimated each model by substituting the mean per capita expenditures for median per capita expenditures; the results are similar.
} 
evidence showing that the poor spend up to several years of income to bury an important member in South Africa (Case, Garrib, and Olgiati 2008) and in Ghana (Economist 2007). 
Table 5. OLS regressions for funeral expenses

\begin{tabular}{|c|c|c|c|c|}
\hline & Gini & SK $^{1}$ & $\mathbf{K T}^{\mathbf{2}}$ & SK * KT \\
\hline \multirow[t]{2}{*}{ Per capita income in 2004 (log RMB) } & 0.049 & 0.082 & 0.092 & 0.091 \\
\hline & $(0.82)$ & $(0.71)$ & $(0.68)$ & $(0.68)$ \\
\hline \multirow[t]{2}{*}{ Male head of household (dummy) } & $-0.661 * *$ & $-0.617^{*}$ & $-0.626^{*}$ & $-0.628 *$ \\
\hline & $(0.03)$ & $(0.07)$ & $(0.06)$ & $(0.06)$ \\
\hline \multirow[t]{2}{*}{ Education of household head (years) } & 0.024 & 0.024 & 0.023 & 0.022 \\
\hline & $(0.41)$ & $(0.43)$ & $(0.44)$ & $(0.46)$ \\
\hline \multirow[t]{2}{*}{ Minority head of household (dummy) } & -0.154 & -0.149 & -0.119 & -0.116 \\
\hline & $(0.50)$ & $(0.50)$ & $(0.57)$ & $(0.59)$ \\
\hline \multirow[t]{2}{*}{ Cadre family } & -0.044 & 0.026 & 0.007 & -0.034 \\
\hline & $(0.90)$ & $(0.94)$ & $(0.98)$ & $(0.91)$ \\
\hline \multirow[t]{2}{*}{ Share of household members aged 11-29, unmarried } & $0.896 * *$ & $0.886^{* *}$ & $0.876^{* *}$ & $0.899 * *$ \\
\hline & $(0.03)$ & $(0.03)$ & $(0.03)$ & $(0.02)$ \\
\hline \multirow[t]{2}{*}{ Share of household members aged 60 and above } & $0.637 *$ & $0.742 * *$ & $0.789 * *$ & $0.797 * *$ \\
\hline & $(0.09)$ & $(0.05)$ & $(0.03)$ & $(0.03)$ \\
\hline \multirow[t]{2}{*}{ Median expenditure per occasion in previous year $(\log R M B)$} & $0.199 * *$ & $0.187 * *$ & $0.183 * *$ & $0.182 * *$ \\
\hline & $(0.01)$ & $(0.03)$ & $(0.04)$ & $(0.04)$ \\
\hline \multirow[t]{2}{*}{ Dummy for bottom $25 \%$ of households in natural village (2004) } & -0.178 & 0.170 & 0.140 & 0.230 \\
\hline & $(0.88)$ & $(0.72)$ & $(0.75)$ & $(0.57)$ \\
\hline \multirow[t]{2}{*}{ Dummy for top $25 \%$ of households in natural village (2004) } & -1.532 & -0.066 & -0.013 & 0.057 \\
\hline & $(0.16)$ & $(0.82)$ & $(0.97)$ & $(0.83)$ \\
\hline \multirow[t]{2}{*}{ Income distribution * Dummy for bottom $25 \%$ of households in natural village } & -0.014 & 0.073 & $0.020 *$ & $0.004 * *$ \\
\hline & $(0.56)$ & $(0.39)$ & $(0.06)$ & $(0.03)$ \\
\hline \multirow[t]{2}{*}{ Income distribution * Dummy for middle $50 \%$ of households in natural village } & -0.027 & -0.030 & -0.004 & 0.000 \\
\hline & $(0.18)$ & $(0.65)$ & $(0.53)$ & $(0.44)$ \\
\hline \multirow[t]{2}{*}{ Income distribution * Dummy for top $25 \%$ of households in natural village } & 0.015 & 0.096 & 0.017 & $0.004 *$ \\
\hline & $(0.29)$ & $(0.22)$ & $(0.15)$ & $(0.10)$ \\
\hline R-squared & 0.249 & 0.241 & 0.248 & 0.249 \\
\hline $\mathrm{AIC}$ & 439 & 441 & 439 & 439 \\
\hline $\mathrm{N}$ & 170 & 170 & 170 & 170 \\
\hline
\end{tabular}

Source: Authors' survey data.

Notes: ${ }^{1}$ SK refers to the skewness of per capita income in the natural village.

${ }^{2} \mathrm{KT}$ refers to the kurtosis of per capita income in the natural village.

$p$-values (shown in parentheses) reflect standard errors clustered by natural villages. *, **, and *** indicate confidence levels of $90 \%, 95 \%$, and $99 \%$, respectively. Administrative village fixed effects are included but not reported here. 
Given such results, status competition among the poor may also be evident for highly visible expenditures associated with weddings. Because the groom's family bears most of the responsibility for expenses related to marriage and captures most of the status associated with a grandiose wedding, we analyze the determinants of wedding expenditures separately for the groom's family ${ }^{23}$ and for the bride's family.

For spending among groom families (Table 6a), interactions between the low-income group dummy and higher moments of the income distribution within the reference population again point to status competition. As kurtosis and skewness increase, spending on weddings among the poor increases, suggesting that local competition correlates with higher spending. These results are consistent with Wei and Zhang (2009), who demonstrated that high sex ratios have increasingly squeezed the rural poor in recent decades, leaving a large share of men unable to find wives. Interestingly, the skewness $\times$ kurtosis interaction, a better measure of local density in tails of income distribution, is also positive and statistically significant for the top 25 percent of the income distribution, suggesting that the rich are not immune to status competition through marriage (note that there is no analogous evidence for middleincome households). However, community norms in the form of lagged median expenditures do not strongly affect wedding expenditures made by the groom's family.

As opposed to the mounting pressure for grooms, marriage markets have become more favorable for brides, and their families are thus less likely to engage in positional spending on weddings. Indeed, in most of rural China, women formally join the husband's family at the time of marriage (Wolf and Huang 1980), so the status value of wedding expenses for a bride's family is limited. Such results are evident in Table $6 \mathrm{~b}$, which shows that wedding spending is largely orthogonal to income, lagged expenditures on weddings, and the income distribution. ${ }^{24}$ However, the education of the household head has a strong effect on wedding expenditures, with an extra year of education raising marital expenditures by approximately 12.5 percent on average, ceteris paribus. ${ }^{25}$ At the same time, wedding spending among minority households is significantly lower than among nonminority households. These results suggest that although wedding spending for the groom's family is indeed positional in nature, wedding spending for the bride's family is subject neither to positional concerns nor to herding behavior; rather, demographics figure prominently into wedding expenditures for the bride's family.

\footnotetext{
${ }^{23}$ To avoid double counting of newly established households, we restrict the sample to households in which the head is aged 40 or above in 2006; the results are robust to other age cutoffs.

${ }^{24}$ The sole exception is for the interaction between the Gini index and the high-income dummy. This result suggests that the wealthy provide larger dowries to their daughters as local income competition shrinks; however, the other point estimates do not support this conclusion.

${ }^{25}$ This result is consistent with Brown (2009), who showed that some rural Chinese parents attempt to influence the status of their daughters in their conjugal homes by providing brides with more assets upon marriage.
} 
Table 6a. OLS regressions for wedding expenses paid by the groom's family

\begin{tabular}{|c|c|c|c|c|}
\hline & Gini & SK $^{1}$ & $\mathbf{K T}^{2}$ & SK * KT \\
\hline \multirow[t]{2}{*}{ Per capita income in $2006(\log \mathrm{RMB})$} & 0.205 & 0.181 & 0.186 & 0.188 \\
\hline & $(0.59)$ & $(0.46)$ & $(0.42)$ & $(0.40)$ \\
\hline \multirow[t]{2}{*}{ Male head of household (dummy) } & -0.381 & -0.419 & -0.451 & -0.459 \\
\hline & $(0.17)$ & $(0.19)$ & $(0.17)$ & $(0.16)$ \\
\hline \multirow[t]{2}{*}{ Education of household head (years) } & 0.040 & 0.040 & 0.042 & 0.044 \\
\hline & $(0.66)$ & $(0.33)$ & $(0.30)$ & $(0.28)$ \\
\hline \multirow[t]{2}{*}{ Minority head of household (dummy) } & $-0.161 * *$ & -0.112 & -0.098 & -0.115 \\
\hline & $(0.02)$ & $(0.52)$ & $(0.58)$ & $(0.51)$ \\
\hline \multirow[t]{2}{*}{ Cadre family } & -0.178 & -0.213 & -0.211 & -0.210 \\
\hline & $(0.69)$ & $(0.48)$ & $(0.47)$ & $(0.47)$ \\
\hline \multirow[t]{2}{*}{ Share of household members aged 11-29, unmarried } & 1.296 & $1.319 * *$ & $1.340 * *$ & $1.339 * *$ \\
\hline & $(0.24)$ & $(0.04)$ & $(0.04)$ & $(0.04)$ \\
\hline \multirow[t]{2}{*}{ Share of household members aged 60 and above } & -0.109 & -0.085 & -0.089 & -0.090 \\
\hline & $(0.87)$ & $(0.85)$ & $(0.84)$ & $(0.84)$ \\
\hline \multirow[t]{2}{*}{ Median expenditure per occasion in previous year (log RMB) } & -0.001 & -0.004 & -0.006 & -0.007 \\
\hline & $(0.99)$ & $(0.93)$ & $(0.91)$ & $(0.90)$ \\
\hline \multirow[t]{2}{*}{ Dummy for bottom $25 \%$ of households in natural village (2004) } & 1.147 & 0.183 & 0.209 & 0.259 \\
\hline & $(0.34)$ & $(0.68)$ & $(0.58)$ & $(0.43)$ \\
\hline \multirow[t]{2}{*}{ Dummy for top $25 \%$ of households in natural village (2006) } & 0.289 & -0.291 & -0.344 & -0.294 \\
\hline & $(0.88)$ & $(0.50)$ & $(0.35)$ & $(0.42)$ \\
\hline \multirow[t]{2}{*}{ Income distribution * Dummy for bottom $25 \%$ of households in natural village } & -0.005 & $0.149 *$ & $0.024 * *$ & $0.005 * * *$ \\
\hline & $(0.14)$ & $(0.08)$ & $(0.01)$ & $(0.01)$ \\
\hline \multirow[t]{2}{*}{ Income distribution * Dummy for middle $50 \%$ of households in natural village } & 0.016 & 0.060 & 0.010 & 0.000 \\
\hline & $(0.55)$ & $(0.45)$ & $(0.43)$ & $(0.49)$ \\
\hline \multirow[t]{2}{*}{ Income distribution * Dummy for top $25 \%$ of households in natural village } & 0.002 & 0.108 & $0.025^{*}$ & $0.005 * * *$ \\
\hline & $(0.95)$ & $(0.51)$ & $(0.06)$ & $(0.01)$ \\
\hline R-squared & 0.321 & 0.326 & 0.33 & 0.331 \\
\hline $\mathrm{AIC}$ & 339 & 366 & 365 & 365 \\
\hline $\mathrm{N}$ & 129 & 129 & 129 & 129 \\
\hline
\end{tabular}

Source: Authors' survey data.

Notes: ${ }^{1} \mathrm{SK}$ refers to the skewness of per capita income in the natural village.

${ }^{2} \mathrm{KT}$ refers to the kurtosis of per capita income in the natural village.

3 To avoid double counting of newly established households, we restrict the sample to households with heads aged 40 or above in 2006 (results are robust to other cutoffs). $p$-values (shown in parentheses) reflect standard errors clustered by natural villages. *, **, and *** indicate confidence levels of $90 \%, 95 \%$, and $99 \%$, respectively. Village fixed effects are included but not reported here. 
Table 6b. OLS regressions for wedding expenses paid by the bride's family

\begin{tabular}{|c|c|c|c|c|}
\hline & Gini & SK $^{1}$ & $\mathbf{K T}^{\mathbf{2}}$ & SK * KT \\
\hline \multirow[t]{2}{*}{ Per capita income in 2004 (log RMB) } & -0.130 & 0.002 & -0.015 & -0.015 \\
\hline & $(0.62)$ & (0.99) & $(0.95)$ & $(0.95)$ \\
\hline \multirow[t]{2}{*}{ Male head of household (dummy) } & 0.326 & 0.266 & 0.334 & 0.370 \\
\hline & $(0.59)$ & $(0.69)$ & $(0.60)$ & $(0.56)$ \\
\hline \multirow[t]{2}{*}{ Education of household head (years) } & $0.128 * * *$ & $0.129 * * *$ & $0.124 * * *$ & $0.122 * * *$ \\
\hline & $(0.00)$ & $(0.00)$ & $(0.00)$ & $(0.00)$ \\
\hline \multirow[t]{2}{*}{ Minority head of household (dummy) } & $-0.516^{* *}$ & $-0.535 * *$ & $-0.535 * *$ & $-0.532 * *$ \\
\hline & $(0.02)$ & $(0.03)$ & $(0.03)$ & $(0.03)$ \\
\hline \multirow[t]{2}{*}{ Cadre family } & -0.326 & -0.341 & -0.369 & -0.436 \\
\hline & $(0.66)$ & $(0.67)$ & $(0.67)$ & $(0.64)$ \\
\hline \multirow[t]{2}{*}{ Share of household members aged 11-29, unmarried } & 0.659 & 0.672 & 0.679 & 0.710 \\
\hline & $(0.40)$ & $(0.37)$ & $(0.38)$ & $(0.36)$ \\
\hline \multirow[t]{2}{*}{ Share of household members aged 60 and above } & -0.873 & -0.940 & -0.904 & -0.874 \\
\hline & $(0.25)$ & $(0.23)$ & $(0.26)$ & $(0.28)$ \\
\hline \multirow{2}{*}{ Median expenditure per occasion in previous year $(\log R M B)$} & 0.033 & 0.034 & 0.035 & 0.035 \\
\hline & $(0.51)$ & $(0.52)$ & $(0.51)$ & $(0.52)$ \\
\hline \multirow[t]{2}{*}{ Dummy for bottom $25 \%$ of households in natural village (2004) } & 0.291 & -0.357 & -0.080 & 0.066 \\
\hline & $(0.92)$ & $(0.62)$ & $(0.89)$ & $(0.89)$ \\
\hline \multirow[t]{2}{*}{ Dummy for top $25 \%$ of households in natural village (2004) } & -0.957 & 0.298 & 0.458 & 0.513 \\
\hline & $(0.61)$ & $(0.55)$ & $(0.28)$ & $(0.19)$ \\
\hline \multirow[t]{2}{*}{ Income distribution * Dummy for bottom $25 \%$ of households in natural village } & -0.003 & 0.255 & 0.032 & 0.005 \\
\hline & $(0.95)$ & $(0.15)$ & $(0.16)$ & $(0.21)$ \\
\hline \multirow[t]{2}{*}{ Income distribution * Dummy for middle $50 \%$ of households in natural village } & 0.002 & -0.029 & 0.004 & 0.002 \\
\hline & $(0.97)$ & $(0.84)$ & $(0.76)$ & $(0.48)$ \\
\hline \multirow[t]{2}{*}{ Income distribution * Dummy for top $25 \%$ of households in natural village } & $0.044 * *$ & 0.108 & 0.017 & 0.004 \\
\hline & $(0.02)$ & $(0.32)$ & $(0.39)$ & $(0.40)$ \\
\hline R-squared & 0.311 & 0.309 & 0.306 & 0.305 \\
\hline $\mathrm{AIC}$ & 297 & 297 & 297 & 297 \\
\hline $\mathrm{N}$ & 102 & 102 & 102 & 102 \\
\hline
\end{tabular}

Source: Authors' survey data.

Notes: ${ }^{1}$ SK refers to the skewness of per capita income in the natural village.

${ }^{2} \mathrm{KT}$ refers to the kurtosis of per capita income in the natural village.

$p$-values (shown in parentheses) reflect standard errors clustered by natural village. *, **, and *** indicate confidence levels of $90 \%, 95 \%$, and $99 \%$, respectively. Administrative village fixed effects are included but not reported here. 
Although the evidence clearly points to the positional nature of funeral expenditures and groom's wedding expenditures, especially among the poor, the strength of the results may be attenuated by the fact that income figures are based on 2004 data and, in many cases, were taken well after the funerals and weddings had occurred. The relatively small number of funerals and weddings in any given year precludes focusing exclusively on the period subsequent to 2004. However, because gift giving is commonplace in China, we are able to validate the results for funerals and weddings by evaluating the effect of changes in the key explanatory variables on changes in gift spending between 2004 and 2006. Moreover, given the large number of gift exchanges, we allow for different data-generating processes by income group by evaluating the determinants of gift spending separately for each income group. Unlike spending on funerals and weddings, however, gift giving is often reciprocal in nature; as such, the underlying motivation for spending on gifts may differ. For example, as mentioned, risk sharing and informal insurance networks may underlie the rapid increases in gift expenditures depicted in Figure 1. Therefore, in the regressions that follow, we control for the number of "big events" (reflecting adverse income shocks) that may prompt gift exchange within insurance networks. ${ }^{26}$

Table 7a describes the determinants of changes in the level of gift giving between 2004 and 2006 among the poorest quartile of households, as measured in 2004. Changes in per capita income have a pronounced effect on changes in gift expenditures over the same period; ceteris paribus, a 1 percent increase in the growth of per capita incomes is associated with a 0.72 percent increase in gift spending, which is statistically significant at the 1 percent level across all four specifications. Changes in the median gift expenditure in the natural village are also associated with increased spending on gifts; holding other correlates fixed, a 1 percent greater increase in the median level of spending on gifts in the village is associated with a 0.65 percent increase in individual gift spending. This effect is significant at the 10 percent level when controlling for three of the four income distributions and falls just short of conventional statistical significance levels for the fourth.

Although the magnitudes of the estimates differ, these general patterns persist for middle-income (Table 7b) and high-income (Table 7c) households. Ceteris paribus, a 1 percent increase in the change in income is associated with a 0.28 percent increase in gift spending for middle-income households and a 0.37 percent increase in gift spending for high-income households, each of which is significant at the 5 percent level. For middle-income households, the elasticity of changes in gift spending with respect to changes in the median spending level exceeds unity (significant at the 1 percent level), suggesting that such households are highly responsive to community norms. For high-income households, on the other hand, the estimated effect of median gift expenditures is positive but not statistically significant.

Note that the shock variable does not enter significantly, which confirms that our dependent variable captures gift giving rather than risk sharing. Indeed, in our study area, informal insurance is mostly organized via zero-interest loans, not via the exchange of gifts. For example, in 2006, 68.4 percent of households had access to loans, and 73.4 percent of those loans carried a zero interest rate.

Finally, to distinguish between evolving social norms and status competition, we again report the effect of changes in the four measures of the income distribution on gift expenditures. Results are reported in the last row of each table. For poor households, higher moments of the income distribution are associated with increased spending on gifts (significant at the 1 percent level), suggesting that a higher density of households with similar incomes spurs positional spending. Similar results are evident for middle-income households; ceteris paribus, a 1-point increase in the Gini index prompts a 2.5 percent increase in gift spending (significant at the 1 percent level). In contrast, gift expenditures among wealthy households are not influenced by the income distribution.

\footnotetext{
${ }^{26}$ This variable measures the number of funerals, major illnesses, and widespread deaths of livestock in the natural village; illnesses and livestock losses are included if the total value exceeds twice the average income in the village in that year.
} 
Table 7a. OLS regressions for changes in gift giving for low-income households (2004-2006)

\begin{tabular}{|c|c|c|c|c|}
\hline & Gini & SK $^{1}$ & $\mathbf{K T}^{2}$ & $\mathbf{S K} * \mathbf{K T}$ \\
\hline \multirow{2}{*}{ Change in per capita income (log RMB) } & $0.694 * * *$ & $0.708 * * *$ & $0.716 * * *$ & $0.721 * * *$ \\
\hline & $(0.00)$ & $(0.00)$ & $(0.00)$ & $(0.00)$ \\
\hline \multirow[t]{2}{*}{ Man as household head (dummy) } & 0.595 & 0.693 & 0.792 & 0.779 \\
\hline & $(0.58)$ & $(0.54)$ & $(0.50)$ & $(0.50)$ \\
\hline \multirow[t]{2}{*}{ Education of household head (years) } & -0.047 & -0.030 & -0.030 & -0.031 \\
\hline & $(0.51)$ & $(0.67)$ & $(0.67)$ & $(0.66)$ \\
\hline \multirow[t]{2}{*}{ Minority head of household (dummy) } & 0.611 & 0.491 & 0.431 & 0.420 \\
\hline & $(0.27)$ & $(0.36)$ & $(0.42)$ & $(0.44)$ \\
\hline \multirow[t]{2}{*}{ Cadre family } & -0.643 & -0.695 & -0.743 & -0.763 \\
\hline & $(0.46)$ & $(0.34)$ & $(0.29)$ & $(0.29)$ \\
\hline \multirow[t]{2}{*}{ Share of household members aged 11-29, unmarried } & 0.975 & 1.008 & 1.056 & 1.089 \\
\hline & $(0.25)$ & $(0.22)$ & $(0.20)$ & $(0.19)$ \\
\hline \multirow[t]{2}{*}{ Share of household members aged 60 and above } & -0.539 & -0.477 & -0.435 & -0.432 \\
\hline & $(0.62)$ & $(0.66)$ & $(0.69)$ & $(0.69)$ \\
\hline \multirow[t]{2}{*}{ Change in the number of big events in natural village } & -0.043 & -0.024 & -0.030 & -0.036 \\
\hline & $(0.30)$ & $(0.55)$ & $(0.43)$ & $(0.35)$ \\
\hline \multirow[t]{2}{*}{ Change in median per capita gift expenditure in natural village } & $0.659 *$ & 0.606 & $0.650 *$ & $0.646^{*}$ \\
\hline & $(0.10)$ & $(0.12)$ & $(0.08)$ & $(0.09)$ \\
\hline \multirow[t]{2}{*}{ Change in income distribution at the natural village level } & 0.006 & $0.199 *$ & $0.033 * *$ & $0.006^{* *}$ \\
\hline & $(0.77)$ & $(0.08)$ & $(0.01)$ & $(0.02)$ \\
\hline R-squared & 0.161 & 0.177 & 0.186 & 0.185 \\
\hline $\mathrm{AIC}$ & 605 & 603 & 601 & 601 \\
\hline $\mathrm{N}$ & 138 & 138 & 138 & 138 \\
\hline \multicolumn{5}{|l|}{ Source: Authors' survey data. } \\
\hline \multicolumn{5}{|l|}{ Notes: } \\
\hline \multicolumn{5}{|l|}{${ }^{1} \mathrm{SK}$ refers to the skewness of per capita income in the natural village. } \\
\hline \multicolumn{5}{|l|}{${ }^{2} \mathrm{KT}$ refers to the kurtosis of per capita income in the natural village. } \\
\hline \multicolumn{5}{|c|}{$\begin{array}{l}{ }^{3} \text { This variable measures the number of funerals, major illnesses, and widespread deaths of livestock in the natural village; illnesses and livestock losses are included if the total } \\
\text { value exceeds twice the average income in the village in that year. }\end{array}$} \\
\hline
\end{tabular}


Table 7b. OLS regressions for changes in gift giving in middle-income households (2004-2006)

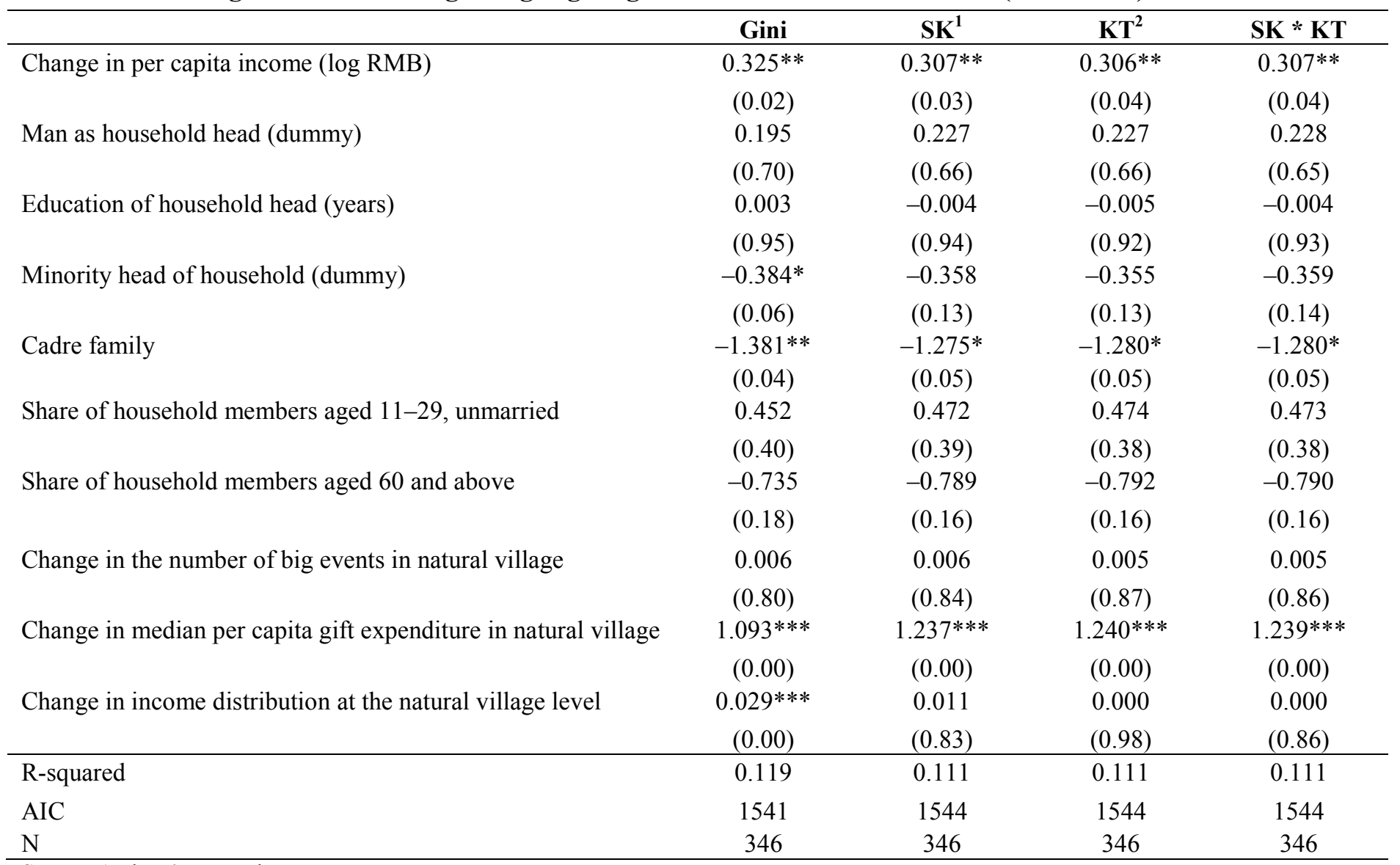

Source: Authors' survey data.

Notes: ${ }^{1}$ SK refers to the skewness of per capita income in the natural village.

${ }^{2} \mathrm{KT}$ refers to the kurtosis of per capita income in the natural village.

${ }^{3}$ This variable measures the number of funerals, major illnesses, and widespread deaths of livestock in the natural village; illnesses and livestock losses are included if the total value exceeds twice the average income in the village in that year.

$p$-values (shown in parentheses) reflect standard errors clustered by natural village. *, **, and *** indicate confidence levels of 90 percent, 95 percent, and 99 percent, respectively. Administrative village fixed effects are included but not reported here. 
Table 7c. OLS regressions for changes in gift giving in high-income households (2004-2006)

\begin{tabular}{|c|c|c|c|c|}
\hline & Gini & SK $^{1}$ & $\mathbf{K T}^{2}$ & $\mathbf{S K} * \mathbf{K T}$ \\
\hline \multirow[t]{2}{*}{ Change in per capita income (log RMB) } & $0.365^{* *}$ & $0.363 * *$ & $0.365^{* *}$ & $0.367 * *$ \\
\hline & $(0.03)$ & $(0.03)$ & $(0.03)$ & $(0.03)$ \\
\hline Man as household head (dummy) & $(0.01)$ & $(0.01)$ & $(0.01)$ & $(0.01)$ \\
\hline \multirow[t]{2}{*}{ Education of household head (years) } & 0.030 & 0.037 & 0.036 & 0.035 \\
\hline & $(0.66)$ & $(0.60)$ & $(0.61)$ & $(0.61)$ \\
\hline Minority head of household (dummy) & $(0.64)$ & $(0.72)$ & $(0.70)$ & $(0.71)$ \\
\hline \multirow[t]{2}{*}{ Cadre family } & -0.912 & -0.867 & -0.876 & -0.875 \\
\hline & $(0.24)$ & $(0.26)$ & $(0.26)$ & $(0.26)$ \\
\hline \multirow[t]{2}{*}{ Share of household members aged 11-29, unmarried } & 0.066 & 0.107 & 0.106 & 0.101 \\
\hline & $(0.92)$ & $(0.87)$ & $(0.88)$ & $(0.88)$ \\
\hline Change in the number of big events in natural village & $(0.22)$ & $(0.27)$ & $(0.23)$ & $(0.23)$ \\
\hline \multirow[t]{2}{*}{ Change in median per capita gift expenditure in natural village } & 0.367 & 0.304 & 0.316 & 0.315 \\
\hline & $(0.22)$ & $(0.29)$ & $(0.28)$ & $(0.28)$ \\
\hline \multirow[t]{2}{*}{ Change in income distribution at the natural village level } & -0.009 & 0.058 & 0.007 & 0.001 \\
\hline & $(0.55)$ & $(0.52)$ & $(0.61)$ & $(0.62)$ \\
\hline R-squared & 0.104 & 0.104 & 0.104 & 0.104 \\
\hline $\mathrm{AIC}$ & 956 & 956 & 956 & 956 \\
\hline $\mathrm{N}$ & 214 & 214 & 214 & 214 \\
\hline
\end{tabular}

Source: Authors' survey data.

Notes: ${ }^{1} \mathrm{SK}$ refers to the skewness of per capita income in the natural village.

${ }^{2} \mathrm{KT}$ refers to the kurtosis of per capita income in the natural village.

${ }^{3}$ This variable measures the number of funerals, major illnesses, and widespread deaths of livestock in the natural village; illnesses and livestock losses are included if the total value exceeds twice the average income in the village in that year.

$p$-values (shown in parentheses) reflect standard errors clustered by natural village. *, **, and *** indicate confidence levels of 90 percent, 95 percent, and 99 percent, respectively. Administrative village fixed effects are included but not reported here. 
Overall, these results provide mixed evidence for the rank-based status model. Although community norms clearly affect spending on funerals and gifts, income distributions also influence some categories of spending for some income groups. Specifically, poor households increase expenditures on funerals, weddings (conditional on being related to the groom), and gifts when the density mass in their part of the income distribution rises - that is, as there is more local competition. In contrast, spending on weddings by brides' families, though equally visible, is better described by other motives for the poor. For middle-income and upper-income households, however, the income distribution does not systematically affect the level of expenditures on funerals or gifts, suggesting that herding behavior may be driving recent escalations in spending in these areas (or that status seeking is perhaps better described by another model that is not based on rank-based utility). Thus, the data suggest that the model is particularly suitable for describing the behavior of the poorest segment of society, while the behavior of high-income groups may be guided by other motives. In addition, results show that competition for status is most intense among those who can least afford to compete. 


\section{DISCUSSION AND CONCLUSIONS}

Many empirical studies of status-conferring consumption have focused on developed countries and affluent segments of society. This paper provides evidence that status-seeking consumption also exists among the poor people in developing countries. Rural parts of developing counties provide an ideal setting for studying this phenomenon, because close social interactions and tight social bonds imply readily identifiable reference groups. Moreover, status seeking through socially observable consumption is a particularly salient phenomenon in the context of extensive rural poverty. The patterns, mechanisms, and welfare consequences of status consumption in developing countries thus deserve additional attention from scholars. China affords a unique opportunity for studying status-conferring spending, in part because rapid changes in income and its distribution within rural communities provide a context in which status races may be triggered.

By using a unique census-type household panel in 26 natural villages in a remote mountainous area of China, we show that social spending has escalated, rising faster than income. Our empirical evidence shows that household spending on funerals and gifts is positively and significantly correlated with lagged median levels of spending in the village. Thus, households follow the reference group's pattern of spending, potentially lowering the welfare of all villagers. By contrast, in the reference group, wedding expenses are not affected by such spending. Patterns of positional spending thus appear to depend on the expenditure category and the income group concerned.

Both herding behavior and status concerns are consistent with increased levels of social spending. To distinguish between these two phenomena, we consider the effects of interactions between income distribution (including higher moments) and income groups on social spending; as far as we are aware, this paper is among the first to take this approach. In essence, this approach amounts to testing the rankbased status model developed by Frank (1985b), Robson (1992) and Hopkins and Kornienko (2004). Individuals in society compete for a high rank, which may invite socially wasteful races for status through excessive positional spending. The rank-based model thus predicts that social spending should be responsive to higher order terms of the income distribution in the reference population. This is because changing the "density" of households with similar incomes changes the intensity of status competition among individuals within that income group. In other words, if social spending is correlated with the number of households in the comparison group, then it is consistent with rank-based status seeking (and arguably inconsistent with norm-induced herding or risk sharing).

Although we cannot rule out herding behavior in the case of gift spending for middle-income and high-income households, the fact that the poor spend more on funerals, weddings (for the grooms' families), and gifts when the local density of poor people increases suggests that such spending patterns are indeed positional. Participating in gift exchange and paying high brideprices may be particularly acute among the families of young men, some of whom may be rationed out of the marriage market in the presence of increasingly unbalanced sex ratios associated with China's One Child Policy (Wei and Zhang 2009). Moreover, whereas gift spending is arguably based on reciprocity and risk sharing, reciprocity is certainly unlikely in the case of funerals and weddings.

Our main findings are that status seeking matters in rural China and that some socially observable goods (but not others) are used as vehicles in the race for status. Moreover, our results suggest that the poor are especially sensitive to status seeking. The results for the poor are consistent with predictions of the rank-based model; however, the same is not true for richer subgroups within our sample. Perhaps competition for status takes a different form for these richer individuals. Our findings also suggest that the grimmest of scenarios does not unfold - that is, people at the bottom of the income distribution have some residual status (our evidence is consistent with the HK model's $\mathrm{s}>0$ case) and can opt out of status races when some of their peers are upgraded to middle-income echelons; they do not desperately scramble for status in a war that cannot be won.

Nevertheless, the welfare consequences of positional externalities associated with such status seeking may be severe for Chinese households living close to subsistence. First and foremost, money 
spent on funerals, weddings, and gifts is not available for consumption or productive investments. Status competition may have potentially adverse health consequences. For example, in 2004, 41 percent of the households in the first administrative village, 29 percent in the second village, and 20 percent in the third village sold blood to supplement their incomes; blood sales brought in 9 percent of the annual income to the mean household that year. Although blood donation stations in the county were shut down due to contamination in late 2006, 9 percent of households continued to rely on blood sales for income, often traveling outside the county to make sales. Qualitative evidence gathered at the time of the survey revealed that many villagers felt compelled to sell blood so they could build houses for their sons' marriages, afford funerals and weddings, and participate in gift giving. Frequent blood sales have also been associated with high local rates of HIV/AIDS (Rosenthal 2000) and hepatitis C (LaFranier 2009) in China, suggesting that the long-term consequences of blood sales may be severe. These findings indicate that it is especially important to keep an eye on positional spending and its welfare consequences in the context of poverty traps. 


\section{REFERENCES}

Anderson, S. 2007. The economics of dowry and bride price. Journal of Economic Perspectives 21(4): 151-174.

Banerjee, A.V. 1992. A simple model of herd behavior. Quarterly Journal of Economics 107(3): 797-817.

Banerjee, A. V., and E. Duflo. 2007. The economic lives of the poor. Journal of Economic Perspectives 21(1): 141167.

Bikhchandani, S., D. Hirshleifer, and I. Welch. 1992. A theory of fads, fashion, custom, and cultural change as informational cascades. Journal of Political Economy 100(5): 992-1026.

Botticini, M., and A. Siow. 2003. Why dowries? American Economic Review 93(4): 1385-1398.

Brown, P. H. 2009. Dowry and intrahousehold bargaining: Evidence from China. Journal of Human Resources 44(1): $25-46$.

Case, A. C., A. Garrib, A. Menendez, and A. Olgiati. 2008. Paying the piper: The high cost of funerals in South Africa. National Bureau of Economic Research (NBER) Working Paper 14456. Cambridge, Mass.: NBER.

Clark, A. E., P. Frijters, and M. Shields. 2008. Relative income, happiness, and utility: An explanation for the Easterlin paradox and other puzzles. Journal of Economic Literature 46: 95-144.

Clark, A. E., and A. J. Oswald. 1998. Comparison-concave utility and following behavior in social and economic settings. Journal of Public Economics 70(1): 133-155.

Cole, H., G. Mailath, and A. Postlewaite. 1992. Social norms, savings behavior, and growth.” Journal of Political Economy 100: 1092-1125.

Coate, S., and M. Ravallion. 1993. Reciprocity without commitment: Characterization of informal insurance arrangements. Journal of Development Economics 40: 1-24.

de Brauw, A., and S. Rozelle. 2008. Migration and household investment in rural China. China Economic Review 19(2): 320-335.

Dekker, M., and H. Hoogeveen. 2002. Bridewealth and household security in rural Zimbabwe. Journal of African Economies 11(1): 114-145.

Diener, E., E. Sandvik, L. Seidlitz, and M. Diener. 1993. The relationship between income and subjective wellbeing: Relative or absolute? Social Indicators Research 28: 195-223.

Duesenberry, J. 1949. Income, saving, and the theory of consumer behavior. Cambridge, Mass.: Harvard University Press.

Easterlin, R. 1995. Will raising the incomes of all increase the happiness of all? Journal of Economic Behavior and Organization 27: 35-48.

Economist. 2007. Can Ghanaians afford such splendid funerals? The Economist, May 24.

Fafchamps, M., and F. Gubert. 2007. The formation of risk sharing networks. Journal of Development Economics 83: $326-350$.

Fafchamps, M., and S. Lund. 2003. Risk sharing networks in rural Philippines. Journal of Development Studies 71: 261-287.

Frank, R. H. 1985a. Choosing the right pond. Oxford: Oxford University Press.

. 1985b. The demand for unobservable and other non-positional goods. American Economic Review 75: 101-116.

. 2005. Positional externalities cause large and preventable welfare losses. American Economic Review

Papers and Proceedings 95(2): 137-141.

. 2008. Should public policy respond to positional externalities? Journal of Public Economics 92(8-9):

$1777-1786$. 
Genicot, G., and D. Ray. 2003. Group formation in risk-sharing arrangements. Review of Economic Studies 70: 87113.

Haagsma, R., and P. van Mouche. 2007. Equilibrium social hierarchies: A non-cooperative ordinal status game. Wageningen University, Discussion Paper. Wageningen, The Netherlands.

Heffetz, O. 2007. Conspicuous consumption and the visibility of consumption expenditures. Ithaca, N.Y.: Cornell University. Photocopy.

Hopkins, E., and T. Kornienko. 2004. Running to keep in the same place: Consumer choice as a game of status. American Economic Review 94: 1085-1107.

LaFranier, S. 2009. China reports hepatitis infections from hospital. New York Times, April 1, page A8.

Ligon, E., J. Thomas, and T. Worrall. 2003. Mutual insurance and limited commitment: Theory and evidence in village economies. Review of Economic Studies 69: 115-139.

Liu, X. 2000. In one's own shadow: An ethnographic account of the condition of post-reform China. Berkeley: University of California Press.

Luttmer, E. 2005. Neighbors as negatives: Relative earnings and well-being. Quarterly Journal of Economics 120: 963-1002.

Oswald, A. 1997. Happiness and economic performance. Economic Journal 107: 1815-1831.

Oxoby, R. 2004. Cognitive dissonance, status, and growth of the underclass. Economic Journal 114: 727-749.

PAO (Puding County Poverty Alleviation and Development Office). 2003. Summary on Puding County antipoverty project. Memo. China.

Pollak, R. 1976. Interdependent preferences. American Economic Review 66: 309-320.

Postlewaite, A. 1998. The social basis of interdependent preferences. European Economic Review 42: 779-800.

Rao, V. 1993. The rising price of husbands: A hedonic analysis of dowry increases in rural India. Journal of Political Economy 101: 666-677.

Robson, A. 1992. Status, the distribution of wealth, private and social attitudes to risk. Econometrica 60: 837-857.

Rosenthal, E. In China, A steep price to pay for poverty: Dying of AIDS. New York Times, October 28, page A1.

Rosenzweig, M. R. 1988. Risk, implicit contracts and the family in rural areas of low-income countries. Economic Journal 98: 1148-1170.

Samuelson, L. 2004. Information-based relative consumption effects. Econometrica 72: 93-118.

Santos, P., and C. B. Barrett. 2008. What do we learn about social networks when we only sample individuals? Not much. Department of Applied Economics and Management Working Paper. Ithaca, N.Y.: Cornell University.

Shilpi, F., and M. Fafchamps. 2003. The spatial division of labor in Nepal. Journal of Development Studies 39(6): $23-66$.

Stutzer, A. 2004. The role of income aspirations in individual happiness. Journal of Economic Behavior and Organization 54(1): 89-110.

Townsend, R. M. 1994. Risk and insurance in village India. Econometrica 62: 539-591.

Udry, C. 1994. Risk and insurance in a rural credit market: An empirical investigation in northern Nigeria. Review of Economic Studies 61: 495-526.

van Kempen, L. 2003. Are the poor willing to pay a premium for designer labels? A field experiment in Bolivia. Oxford Development Studies 32: 205-224.

Veblen, T. 1899. The theory of the leisure class (reprinted in 1965). New York: MacMillan.

Wei, S. J., and X. Zhang. 2009. Sex ratios and savings rates: Evidence from "excess men" in China. NBER Working Paper 15093. Cambridge, Mass.: NBER. 
Whyte, M. 1988. Death in the People's Republic of China. In Death Ritual in Late Imperial and Modern China, eds. J. L. Watson and E. S. Rawski. Berkeley: University of California Press.

Wolf, A. P., and C. Huang. 1980. Marriage and adoption in China, 1845-1945. Palo Alto, Calif.: Stanford University Press.

WHO (World Health Organization). 1995. Physical status: The use and interpretation of anthropometry. Report of a WHO Expert Committee. WHO Technical Report Series 854. Geneva: World Health Organization.

Yan, Y. 1996. The flow of gifts: Reciprocity and social networks in a Chinese village. Palo Alto, Calif.: Stanford University Press.

Zhang, J., and W. Chan. 1999. Dowry and wife's welfare: A theoretical and empirical analysis. Journal of Political Economy 107(4): 786-808.

Zhang, L., A. de Brauw, and S. Rozelle. 2004. China's rural labor market development and its gender implications. China Economic Review 15: 230-247. 




\section{RECENT IFPRI DISCUSSION PAPERS}

\section{For earlier discussion papers, please go to www.ifpri.org/pubs/pubs.htm\#dp. All discussion papers can be downloaded free of charge.}

982. Assessing food security in Yemen: An innovative integrated, cross-sector, and multilevel approach. Olivier Ecker, Clemens Breisinger, Christen McCool, Xinshen Diao, Jose Funes, Liangzhi You, and Bingxin Yu, 2010.

981. Long-term impact of investments in early schooling: Empirical evidence from rural Ethiopia. Subha Mani, John Hoddinott, and John Strauss, 2010.

980. Infrastructure and cluster development: A case study of handloom weavers in Ethiopia. Gezahegn Ayele, Lisa Moorman, Kassu Wamisho, and Xiaobo Zhang, 2010.

979. Country-level impact of global recession and China's stimulus package: A general equilibrium assessment. Xinshen Diao, Yumei Zhang, and Kevin Z. Chen, 2010.

978. Emergence of Sri Lanka in European fish trade: Is there cause for concern in the Lake Victoria Region (East Africa)? Andrew Muhammad and Guyslain Ngeleza, 2010.

977. China has reached the Lewis Turning Point. Xiaobo Zhang, Jin Yang, and Shenglin Wang, 2010.

976. The medium-term impact of the primary education stipend in rural Bangladesh. Bob Baulch, 2010.

975. A review of empirical evidence on gender differences in nonland agricultural inputs, technology, and services in developing countries. Amber Peterman, Julia Behrman, and Agnes Quisumbing, 2010.

974. An experiment on the impact of weather shocks and insurance on risky investment. Ruth Vargas Hill and Angelino Viceisza, 2010.

973. Engendering agricultural research. Ruth Meinzen-Dick, Agnes Quisumbing, Julia Behrman, Patricia Biermayr-Jenzano, Vicki Wilde, Marco Noordeloos, Catherine Ragasa, Nienke Beintema, 2010.

972. Sarpanch Raj: Is the president all powerful? The case of village councils in India. Nethra Palaniswamy, 2010.

971. Asset versus consumption poverty and poverty dynamics in the presence of multiple equilibria in rural Ethiopia. Lenis Saweda O. Liverpool and Alex Winter-Nelson, 2010.

970. Poverty status and the impact of social networks on smallholder technology adoption in rural Ethiopia. Lenis Saweda O. Liverpool and Alex Winter-Nelson, 2010.

969. Wage subsidies to combat unemployment and poverty: Assessing South Africa's options. Justine Burns, Lawrence Edwards, and Karl Pauw, 2010.

968. Patterns and trends of child and maternal nutrition inequalities in Nigeria. Babatunde Omilola, 2010.

967. Foreign inflows and growth challenges for African countries: An intertemporal general equilibrium assessment. Xinshen Diao and Clemens Breisinger, 2010.

966. Biofuels and economic development in Tanzania. Channing Arndt, Karl Pauw, and James Thurlow, 2010.

965. Weathering the storm: Agricultural development, investment, and poverty in Africa following the recent food price crisis. Babatunde Omilola and Melissa Lambert, 2010.

964. Who has influence in multistakeholder governance systems? Using the net-map method to analyze social networking in watershed management in Northern Ghana. Eva Schiffer, Frank Hartwich, and Mario Monge, 2010.

963. How to overcome the governance challenges of implementing NREGA: Insights from Bihar using process-influence mapping. Katharina Raabe, Regina Birner, Madhushree Sekher, K.G. Gayathridevi, Amrita Shilpi, and Eva Schiffer, 2010.

962. Droughts and floods in Malawi: Assessing the economywide effects. Karl Pauw, James Thurlow, and Dirk van Seventer, 2010 .

961. Climate change implications for water resources in the Limpopo River Basin. Tingju Zhu and Claudia Ringler , 2010.

960. Hydro-economic modeling of climate change impacts in Ethiopia. Gene Jiing-Yun You and Claudia Ringler, 2010. 


\section{INTERNATIONAL FOOD POLICY RESEARCH INSTITUTE}

\section{www.ifpri.org}

IFPRI HEADQUARTERS

2033 K Street, NW

Washington, DC 20006-1002 USA

Tel.: +1-202-862-5600

Fax: +1-202-467-4439

Email: ifpri@cgiar.org

IFPRI ADDIS ABABA

P. O. Box 5689

Addis Ababa, Ethiopia

Tel.: +251116463215

Fax: +251116462927

Email: ifpri-addisababa@cgiar.org

IFPRI NEW DELHI

CG Block, NASC Complex, PUSA

New Delhi 110-012 India

Tel.: 9111 2584-6565

Fax: 9111 2584-8008 / 2584-6572

Email: ifpri-newdelhi@cgiar.org 